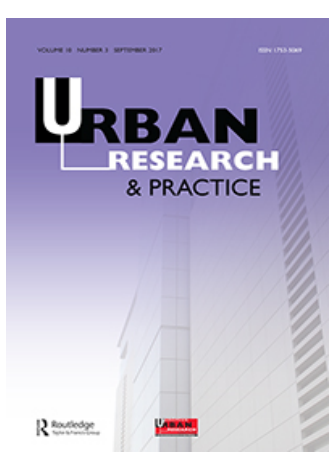

Urban Research \& Practice

\title{
An evaluation of urban regeneration: the effectiveness of a retail-led project in Lisbon
}

\section{Pedro Porfírio Coutinho Guimarães}

To cite this article: Pedro Porfírio Coutinho Guimarães (2017) An evaluation of urban regeneration: the effectiveness of a retail-led project in Lisbon, Urban Research \& Practice, 10:3, 350-366, DOI: $10.1080 / 17535069.2016 .1224375$

To link to this article: https://doi.org/10.1080/17535069.2016.1224375

曲 Published online: 29 Aug 2016.

Submit your article to this journal $\pi$

Џll Article views: 675

View Crossmark data $\asymp$

Citing articles: 1 View citing articles 지 


\title{
An evaluation of urban regeneration: the effectiveness of a retail-led project in Lisbon
}

\author{
Pedro Porfírio Coutinho Guimarães (10* \\ Center for Geographical Studies, Institute of Geography and Spatial Planning, Universidade de \\ Lisboa, Lisbon, Portugal
}

\begin{abstract}
To overcome the decline of the vitality and viability of town centres across several Western European cities, urban regeneration projects have been implemented. Despite their dissemination, there are shortcomings regarding the evaluation of the impacts produced by such projects. We aim to contribute to the existing literature on the subject by undertaking an evaluation of a retail-led urban regeneration project that was implemented in Lisbon's historic centre. We conclude that although there were significant outputs, the project was not effective and did not manage to improve the viability of the area as an important commercial area of Lisbon.
\end{abstract}

Keywords: urban regeneration; retail-led urban regeneration; Lisbon; retail

\section{Introduction}

Several interrelated changes have been experienced in retail in Western Europe since the 1950s (Guimarães forthcoming). Alongside the incorporation of new sales techniques, we have witnessed the concentration of the market share into the hands of some large retailers and/or economic groups. As experienced in other countries, in Sweden during the year $2000,95 \%$ of all grocery purchases were made in establishments belonging to one of the five largest retail companies operating in the country (Bell and Cuthbertson 2004, 66). This may have contributed towards the decline in the number of establishments selling everyday products during the final decades of the twentieth century (Pereira, Teixeira, and Biaggio 2002, 24). Further to this, new formats appeared and disseminated. Enhancing their need for centrality and accessibility, the dissemination of new establishments and shopping facilities began to favour peripheral locations. The preference for this new location was due to the demand for land required to build large shopping facilities and because such places are easily accessible by car. This new location was also as a consequence of the expansion of cities to peripheral areas and, therefore, crucial to meet the needs of a population with an increasing purchasing power and a growing motorisation rate. As a result of this, small and independent retail began to lose its market share. As exemplified by Guy $(2007,133)$, due to their location in the traditional centres of commerce and main town centres, these areas began to decline and lost their vitality and viability. Subsequently, in the majority of Western European countries, national governments started the task of regenerating these areas. Assuming importance in a number of dimensions - from economic and social to historical - these centres have

*Email: pedroguimaraes@campus.ul.pt 
been the target of several urban regeneration strategies, which involved to a greater or lesser extent, the participation of the private sector.

In Portugal, this process was similar, although it happened much slower in comparison to other countries such as the United Kingdom, France or Sweden. Based on retail, the most common measures taken to regenerate town centres in Portugal have been publicly funded retail modernisation programmes, which were implemented in the country during the 1990s and 2000s (Guimarães 2015). Despite recognising their importance - particularly for having provided large sums of money and for having allowed the implementation of projects in numerous town centres - an assessment of their impacts was never undertaken. Several authors have successfully studied the process of retail change in Portugal and have included the retail-led urban regeneration projects in their analysis (see Balsas 2007; Barata-Salgueiro 1996; Cachinho 2002; Fernandes 2012). However, no form of ex-post evaluation was ever produced to assess the impacts of these projects. Although they were developed after Procom implementation, Balsas's (2007) and Fernandes' (2012) works on the subject are relevant but focused mainly on the context in which the projects were created, on the programme characteristics and in some outputs of the projects developed nation-wide. In a similar way, Cachinho's (2002) work also gives attention to the same subjects. BarataSalgueiro book was published before Procom projects were implemented and, therefore, also focused on the existent conditions. Typically, only the main outputs were made available by public institutions (DGAE 2010) and discussed by those authors, leaving the analysis of the impacts to the empirical consideration of local technicians from city councils and chambers of commerce. The opinions of these actors are based on personal estimations without any kind of scientific validation. Furthermore, these are the same actors that are involved in the implementation of these programmes and the self-criticism and evaluation of their own work could be put into question if they stated that it went badly. This consideration is similar to the one produced by Williams (2014) in the preface of Wrigley and Brookes' book (2014), in which he assumed that 'policy makers' and decision takers' approach to new (retail) developments is, all too often, based not on careful and objective consideration of sound evidence but on wild, frequently unsubstantiated, assertions'. Thus, there is a need for an evaluation of the impacts that those programmes had on the area where the intervention took place.

This problem is applicable to other national contexts and to urban regeneration in general, to the extent that Tyler et al. $(2013,169)$ stated that 'although there have been many initiatives designed to regenerate relatively rundown and deprived parts of major urban areas, there have been surprisingly few attempts to value their benefits'. Findlay and Sparks $(2009,3)$ also recognised a shortcoming in the literature that evaluates the impact that revitalisation or regeneration projects have been producing in the territory. Using Lisbon as a case study, this paper aims to expand the existing literature on the subject. Although we recognise the difficulty of doing policy and programme evaluation, we share the same view as Alexander $(2006,8)$. For this author, the objective of an ex-post evaluation is to learn from the experience and make use of the conclusions in the design of future policies and/or programmes.

In Section 2, we will pursue a broader focus on urban regeneration and on retail-led processes as described in the international literature and also in the specific geographical context of Portugal. In Section 3, the material and methods of this study will be described. Section 4 is dedicated to the case study, in which a retail-led urban regeneration project implemented in the historical centre of Lisbon is analysed. Finally, we will draw some concluding remarks. 


\section{Urban regeneration and retail-led urban regeneration}

\subsection{Urban regeneration}

Although there is no single prescribed form, urban regeneration is a widely experienced phenomenon (Roberts and Sykes 2000, 3). Hall $(2006,57)$ considered urban regeneration as a 'proactive set of interventions designed primarily to ameliorate against the negative consequences of urban decline'. In this paper, we will use Roberts' $(2000,17)$ inclusive definition of urban regeneration:

A comprehensive and integrated vision and action which leads to the resolution of urban problems and which seeks to bring about a lasting improvement in the economic, physical, social and environmental condition of an area that has been subject to change.

This process has not been limited to a certain geographical territory and it has been widely used in different contexts, for example, the United Kingdom (Hall 2002; Guy 2007; Tallon 2010), Romania (Alpopi and Manole 2013) and Japan (Sasaki 2010). Apart from being scattered geographically, it uses different sectors as a means of solving the problems which it intends to address. Thus, one may find in the literature, research on culture ledinitiatives (Dinardi 2015; Gunay and Dokmeci 2012; Jung et al. 2015; Lazarevic, Koruznjak, and Devetakovic 2015; Tay and Coca-Stefaniak 2010; Wang 2009); housing-led initiatives (Egan et al. 2015); specific buildings, such as Guggenheim Museum (Plaza 2000); or events, such as the 2012 Olympic Games in London (Davis and Thornley 2010).

\subsection{Retail-led urban regeneration}

Retail has also been used as a means of urban regeneration, this is usually associated with town centre interventions aimed at increasing their vitality and viability following the changes that affected retail and those areas. According to Hall $(2006,60)$, 'inherent in all urban regeneration programmes is some articulation of the causes of the problems they are seeking to address'. Thus, in the case of identified problems (such as the commercial environment of declining quality and quantity, lack of professional management) within retail and town centres, the solution has been to address them. Therefore, traditionally two forms of intervention have been performed: the implementation of new retail formats in the town centre and the introduction of professional and common management in these areas. The Bullring shopping complex in Birmingham is one example of the first type of intervention. Built in the 1960 s, its 2004 renovation was used in the context of the city regeneration process (Jayne 2006, 155). Emery (2006) highlighted some positive outcomes of this renovation, for example, that it not only enhanced the vitality of the area where the Bullring project was implemented, but also in relation to its surroundings and the added status that Birmingham achieved as a retail destination. Another documented example of a similar intervention was the opening of West Quay shopping centre in Southampton in 2000. Lowe's two studies on this shopping centre $(2005,2007)$ confirmed the overall improvement of Southampton in terms of its position in the national ranking of shopping destinations. Furthermore, it concluded that despite increasing the vitality of the area, it focused on the streets closer to the shopping centre, assuming the decline of pedestrian flows in other streets (Lowe 2005, 662). Both examples fit Lee's $(2013,75)$ statement that retail development, which used to take place in the suburbs, has been transformed into mega, post-modern, iconic retail development in inner cities, creating a 
new form of regeneration strategy which Tallon (2008, 2010) called 'mega-retail-led regeneration'. Due to the early impacts of retail decentralisation in the United Kingdom, other examples can be found in the literature regarding case studies in the same country, such as the development of an Asda superstore in Hyson Green. According to Whysall (1995), although it was relevant to create new jobs and to strengthen the area as a retail centrality, this superstore has competed for consumers with the pre-existing small independent retailers. Dixton and Marston's (2003) comprehensive research included the analysis of the Castle Mall shopping centre in Norwich which opened in 1993. As in the cases analysed above, these authors concluded that the opening of the Castle Mall shopping centre improved Norwich as a retail destination.

Usually, this use of retail in urban regeneration processes goes hand-in-hand with urbanistic interventions. One of the most disseminated is pedestrianisation, which is seen as an important instrument in terms of enhancing the attractiveness of commercial areas and in increasing their vitality. Robertson $(1995,430)$ highlighted the importance of this measure in the United States during the 1960s and 1970s in creating pedestrian malls, and Castillo-Mazano et al. (2014) emphasised the positive effects of the pedestrianisation of Asuncion Street and San Jacinto Street, Seville, measured by an increase in citizen satisfaction. The projects of retail-led urban regeneration are, most often, focused on a limited geographical territory, sometimes even a single street or a city quarter. However, it is typically expected that those projects may have multipliers impacts on a wider area, such as on the town centre or could even improve the overall image of the entire city.

In Western Europe, the second type of intervention, related to the introduction of professional and common management of town centres has been put into practice through recognised schemes, such as town centre management (TCM) and Business Improvement Districts (BID), both of which have already been disseminated through a significant number of countries (Coca-Stefaniak et al. 2009; Hoyt 2006, 229; Jones, Hillier, and Comfort 2003, 55; Peel, Lloyd, and Lord 2009, 406; Peel e Lloyd, 2005, 90; Riviezzo, Nisco, and Napolitano 2009, 749; Ward 2007, 658). Despite the importance of this type of urban intervention, there are some drawbacks in relation to the evaluation of the impacts they produced (Ruffin 2008).

Overall, although traditionally it has not been seen as a relevant sector, 'increasingly, retail-led regeneration is seen as an important mechanism to revitalise struggling areas by providing jobs, promoting economic growth and creating attractive places to draw people into the area' (Claxton and Siora 2008, 15).

\subsection{Retail-led urban regeneration in Portugal}

In Portugal, urban regeneration has generally been associated with large-scale urbanistic interventions, such as Expo 98, or small-scale interventions in public spaces usually associated with the rehabilitation of degraded buildings. In Portugal, like in other national contexts, pedestrianisation has been a measure which combines physical intervention in public spaces with the regeneration of commercial areas, especially during the 1990s. Until the negative impacts produced by the peripheral location of new centres of commerce retail was seen as a secondary activity. As a result, the majority of urban regeneration measures focused on the improvement of public spaces and on the rehabilitation of dilapidated buildings. Typically, this was through direct intervention on the public sector or indirectly, when public programmes were put at the disposal of private agents in a bid to boost intervention. In the 1990 s - considering the decline in which the majority of Portuguese city centres were experiencing - there was a change in national retail planning 
policies and the instruments used. Recognising that the decline of the city centre was both a cause and an effect of the decline of its small independent retail a public programme was put into place. Named 'SIMC', this was created in 1991 and aimed to support the modernisation of small independent retail. During this period - learning from the experiences of commercial urbanism developed in France and Belgium - different programmes started to be designed (Guimarães 2013, 2015). In regards to this subject we adopt Mérenne-Schoumaker and Browet's (1988, 119-120) definition of commercial urbanism, not only as the field of urbanism concerned with the localisation of retail, but also in relation to the functional and architectural features, the valorisation of commercial animation and retail centralities, and the criteria used to establish retail floor space. Thus, recognising the limitations of SIMC - a programme that only focused on retail outlets - a new programme was developed. Designed as special projects of commercial urbanism, they have consisted of a combination of funding for retail outlet modernisation and funding for the rehabilitation of the public space and for the creation of events in the commercial areas. Hence in 1994, some legislation began to be made, framing a new programme named 'Procom'. In addition to the financial support for the modernisation of outlets, this programme incorporated funds for the physical rehabilitation of town centres and financial resources to develop and implement a marketing plan to create events and promote town centres. In 1998, 138 projects began to develop in Portugal, both in small towns as well as in medium and large cities. Globally, more than 600 million euros were invested, of which around half were public non-refundable incentives (Table 1).

At the start of the new millennium a new programme named 'Urbcom' was created. This was similar to the previous Procom programme, although it did not achieve the same degree of success. Following the end of this programme in 2008, two others were created and implemented: 'Modcom' and 'Comércio Investe'. The latter still exists in 2016 and it is expected that it will be extended until 2017. Despite being more recent, the financial support for the physical rehabilitation was abolished, which diminished the relevance of these two programmes. With this change, these programmes became similar to SIMC (Table 2).

These two new programmes cannot be considered elements of commercial urbanism because they did not incorporate the public space rehabilitation feature. While there is already some historical background in terms of retail modernisation programmes the most relevant was Procom and Urbcom - both of which incorporated all of the features needed to fit Merenne-Schoumaker and Browet's (1988) concept of commercial urbanism. Although they have been considered crucial in the attempt to increase the vitality and

Table 1. Main characteristics of the PROCOM programme.

\begin{tabular}{llr}
\hline \multicolumn{2}{l}{ Number of projects } & 139 \\
\multicolumn{2}{l}{ Number of supported outlets } & 8114 \\
Outlets modernisation & Investment $(€)$ & $519,293,467$ \\
& Incentive $(€)$ & $262,843,263$ \\
Physical interventions & Investment $(€)$ & $86,880,763$ \\
& Incentive $(€)$ & $43,585,883$ \\
Promotional activities & Investment $(€)$ & $28,197,191$ \\
& Incentive $(€)$ & $21,135,317$ \\
Total & Investment $(€)$ & $634,371,420$ \\
& Incentive $(€)$ & $327,564,463$ \\
\hline
\end{tabular}

Source: DGAE (2010). 
Table 2. Portuguese public programmes for retail modernisation.

\begin{tabular}{lcccc}
\hline & \multicolumn{3}{c}{ Type of investment and targeted entity } \\
\cline { 2 - 5 } & & $\begin{array}{c}\text { Retail } \\
\text { modernisation } \\
\text { (retail outlets) }\end{array}$ & $\begin{array}{c}\text { Public space } \\
\text { rehabilitation (city } \\
\text { council) }\end{array}$ & $\begin{array}{c}\text { Commercial animation } \\
\text { (chambers of } \\
\text { commerce) }\end{array}$ \\
\hline SIMC & $1991-1993$ & $\mathrm{X}$ & $\mathrm{X}$ & \\
PROCOM & $1994-2001$ & $\mathrm{X}$ & $\mathrm{X}$ & $\mathrm{X}$ \\
URBCOM & $2000-2008$ & $\mathrm{X}$ & $\mathrm{X}$ & $\mathrm{X}$ \\
MODCOM & $2005-2010$ & $\mathrm{X}$ & $\mathrm{X}$ & \\
Comércio & $2013-\ldots$ & $\mathrm{X}$ & & $\mathrm{X}$ \\
\multicolumn{1}{l}{ Investe } & & & & \\
\hline
\end{tabular}

Source: Guimarães (2015).

viability of town centres in Portugal, these urban regeneration projects were not evaluated. As stated earlier (Tyler et al. 2013; Findlay and Sparks 2009), this is transversal to other contexts. Following the methodology (Section 3), we will present one case study and empirical findings will be discussed.

\section{Defining our conceptual framework}

As analysed earlier, in the case of the retail-led urban regeneration projects of the Bullring and West Quay shopping centres the evaluation focused on the vitality of the area and its surroundings. The same approach was followed regarding pedestrianisation and new forms of intervention, such as TCM and BID. In our case study, we intend to also use vitality as an indicator of the success of the analysed project. Nevertheless, because we considered it to be limited due to the comprehensive nature of the analysed project, our evaluation research was framed under that concept of effectiveness as defined by the European Commission $(2008,42)$ in the Evalsed Guide. In this document 'the term effectiveness concerns whether the objectives formulated in the programme are being achieved, what the successes and difficulties have been, and how appropriate the solutions chosen have been and what is the influence of external factors that come from outside the programme'. As we can see in Figure 1, other concepts were incorporated in the Evalsed Guide framework.

Considerations such as the relevance, the efficiency or the utility could have been used. Nevertheless, the breadth of the concept of effectiveness, as defined above, allows for a larger, more comprehensive analysis of the impacts and merits of the project and thus was chosen for this research. In order to operationalise this concept, we felt the need to call on a deeper conceptual framework and use the one described by Moore and Spires (2000) based on previous work developed by PACEC. In this framework, the aforementioned authors unveil the way to obtain the net impacts of an urban regeneration programme. Thus, the strategic objectives of the programme should be analysed alongside the inputs, usually represented by the funding (from different sources). The 'activity measures' consist of a stage of outputs representing, for instance, the number of retail units supported or the number of community projects. Considering this last example, the outputs should be analysed according to the number of participants in the mentioned project. At this stage, we get the gross impacts. Nevertheless, and particularly important 


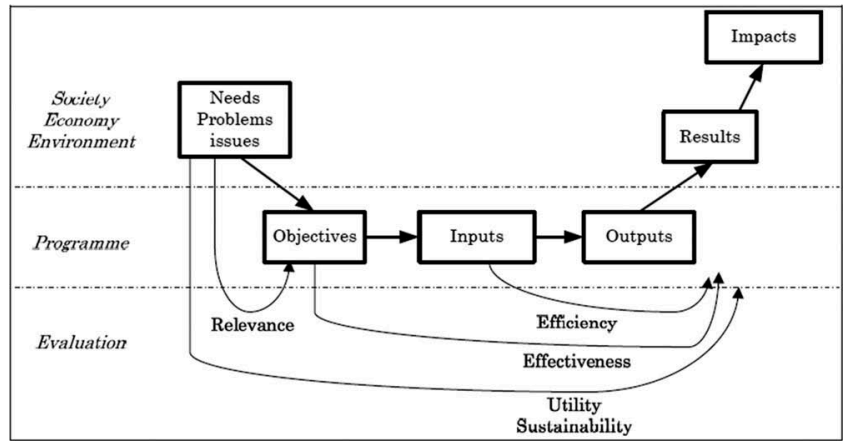

Figure 1. Programme evaluation of the conceptual framework of Evalsed guide. Source: European Commission (2008).

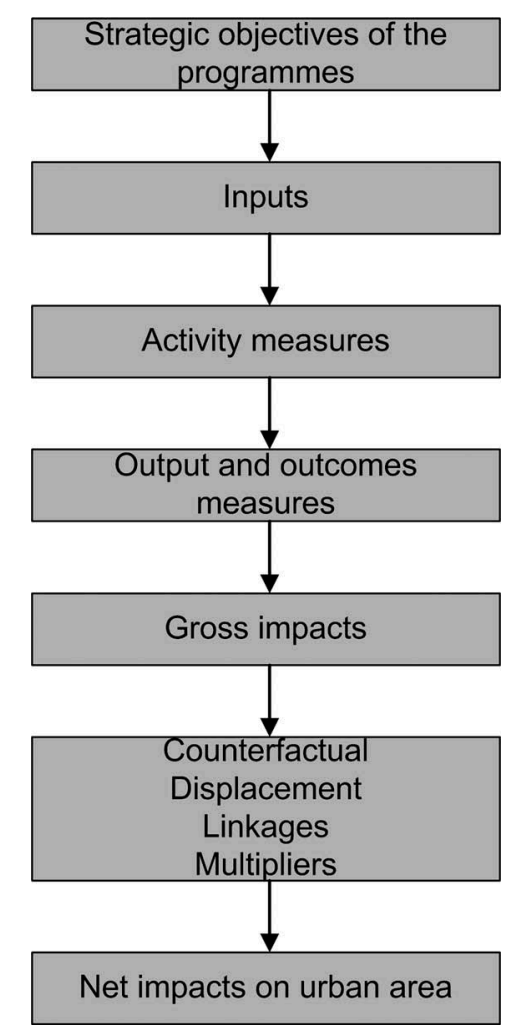

Figure 2. Conceptual framework for the ex-post evaluation of urban regeneration programmes. Source: After Pacec (1999, in Moore and Spires 2000).

when analysing urban areas, one cannot consider the area as if it was a closed system. In fact, urban areas are dynamic and under constant influence of internal and external factors that force them to change. Consequently, obtaining the net impacts is required to obtain more reliable conclusions. Therefore, following the conceptual framework outlined in Figure 2, one may also need to consider the predictable evolution of the analysed subject 
if the programme was not implemented, i.e., the counterfactual. The incorporation of displacement allows us to analyse the indirect negative impacts, which the programme may have produced in a neighbouring area. Finally, linkages and multipliers allow for the consideration of the positive impacts caused by the implemented programme.

The data presented in this article was collected during a research project conducted between 2011 and 2015, which lead to a Ph.D. dissertation in the field of geography and urban planning. In this paper, we will examine Procom and focus on one of the projects financed by this programme: the Baixa Pombalina project implemented in the traditional historic centre of Lisbon. Our hypothesis is that although the Baixa Pombalina Procom project was relevant due to the significant amount of non-refundable incentives that were given to business owners, it was not effective because it failed to both reverse the decline of the area and to recentralise it as a commercial destination.

To fulfil these steps, we will combine qualitative and quantitative approaches, mainly through in-depth interviews. All of the interviews were performed by the author between 2013 and 2014. Two kinds of interviews were developed. In the first case and subjected to a quantitative analysis, 21 business owners that joined the Baixa Pombalina Procom project were interviewed. Because two of the interviewees had more than one outlet in the project, these 21 interviews correspond to 23 outlets. In the second case, two in-depth interviews were performed to relevant stakeholders and academics. Some of the content drawn from these interviews has been included in this article under the designation of 'personal communication'.

\section{Case study}

Lisbon is the capital of Portugal. In 2011, the city had over 500,000 inhabitants within its municipal border and almost 3 million inhabitants in the wider Lisbon metropolitan area. Portugal's network of cities is characterised by its bipolarity - there is a large dependence on the dynamism of the country's two major cities: Lisbon and Oporto. Due to their size, in these two cities it is possible to find an array of different retail centralities, making them unique compared to other Portuguese cities. When Procom was implemented this geographical characteristic stood out. In Lisbon, three different projects were developed. The object of study in this paper is the project developed in Baixa Pombalina, the main traditional centre of commerce and services in Lisbon. Located near the Tagus River, traditionally this area represented the most relevant centre of commerce in the city. The area was rehabilitated after the 1755 earthquake, which destroyed the pre-existing buildings. The reconstruction of Baixa was achieved following the principle that each street should specialise in a certain product or craft which would be recognised in the name of street. Thus, in Baixa streets with names such as 'Gold Street', 'Shoemaker's Street' or 'Silver Street' can be found, toponyms that still reflect the urbanistic interventions developed over two centuries ago. This area represented the old CBD. Since then, the $\mathrm{CBD}$ has moved north into an axis formed by large avenues. It is the most important traditional centre of commerce in Lisbon, and it was here in which, until the final decades of the twentieth century, the headquarters of several major companies, banks and public services were located. Its residential importance has long disappeared and the number of permanent inhabitants has declined. Its importance in terms of tourism still endowed it with a significant vitality, although this has been limited to the early hours of the night. From the 1980 s, this area became threatened by new retail formats, such as the Amoreiras shopping centre, which opened in 1985, the first with a regional catchment area. At the end of the 1990s, two major developments accelerated the change in Lisbon's retail 
structure. The opening of the Colombo shopping centre (with 120,220 $\mathrm{m}^{2}$ of gross leasable area) in a dense urbanised area within the city boundaries stressed this change. The creation of a new centrality in the eastern area of Lisbon - as a consequence of the renovation of an industrial site to give place to a new multi-sectorial centrality that arise was developed to host the World Expo that took place in Lisbon in 1998 - also stressed this. Nevertheless, the reinforcement of existing centralities within the city which happened from the 1980s also contributed to the decline of Baixa Pombalina, putting into question Lisbon's hierarchical structure of centres of commerce. Other bordering areas were also intervened by this programme and other similar programmes. However, Baixa Pombalina still remains an iconic project to this day.

It is in this context that the need to intervene in this area arises, as a way of recentralising Baixa Pombalina as the main retail destination of the city, or at least enhancing its importance. Nevertheless, one should be aware that this context is not unique of this area. As Barata-Salgueiro (2006) points out, urban landscape is under constant change. In 1998, a major global study was performed by Pereira (1998) who realised a series of constraints in Baixa Pombalina as summarised in Table 3.

After this global study, the Procom project was implemented. Due to the mandatory necessity to determine an intervention area, four streets and one square were incorporated into the Baixa Pombalina Procom project: Augusta, Correeiros, Santa Justa, Sapateiros and Rossio square. All of these are in the proximity to São Jorge Castle, as we can see in Figure 3.

Rua Augusta is the main commercial street of this area and one of the most iconic in the country, alongside Rossio, a historic square that defines the northern boundary of Baixa Pombalina. Limiting the intervention to a few streets means better control over the development of the project and makes it possible to establish meetings with all business owners (interviewee 1, on January 2014).

An inquiry undertaken for the global study revealed that 251 outlets existed in the IA. However, only 73 applied for the available funding to modernise their establishments, not only physically but also in terms of sales techniques, marketing and IT equipment. This means just $29 \%$ of outlets applied for funding. According to interviewee 2 (on March 2014), the majority of business owners did not join the project for two reasons. The first reason is related to the passive nature of business owners. Because they were located in a highly regarded area, they did not feel the necessity to adjust their business to consumers, instead assuming the opposite, i.e., that they have always done business this way and, therefore, failed to recognise the necessity to change. The second reason concerns the characteristics of the Portuguese rental market, which until recently favoured tenants over

Table 3. Main reasons that led to the need for intervention.

Outdated establishments

Outdated business practices

Appearance of new centralities

Reinforcement of already existent centres of commerce

Stagnation of the rental market

Lack of parking facilities

Decrease of residents

Inadequacy in the face of increasing motorisation rates

Source: After Pereira (1998). 


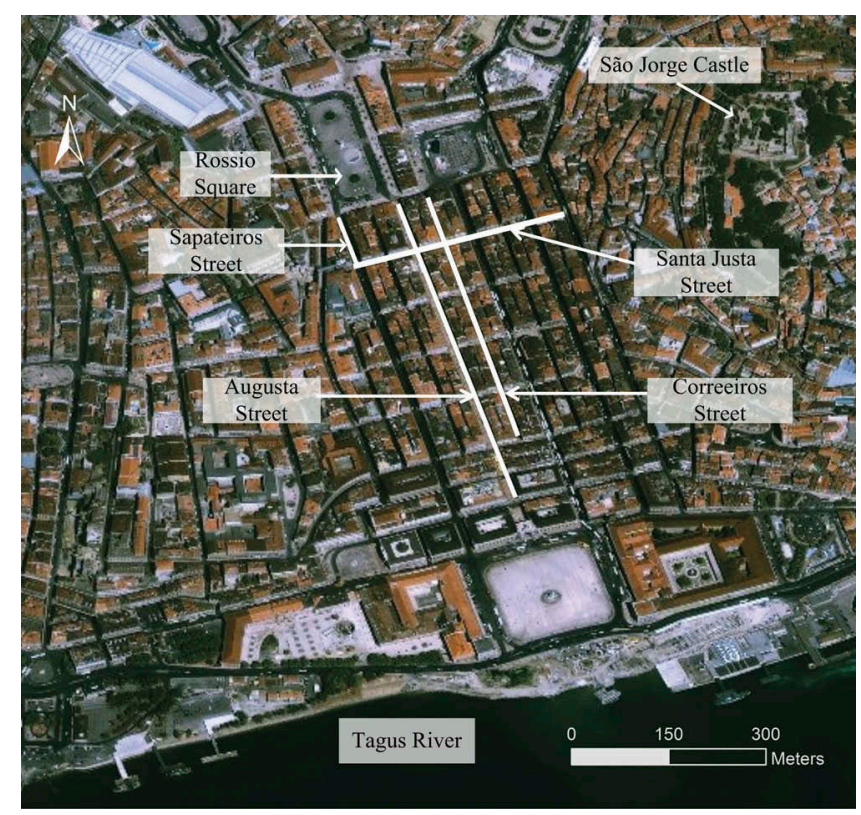

Figure 3. Streets of Lisbon town centre intervened in Baixa Pombalina Procom project. Source: Esri. Treatment performed by the author; year: 2016.

owners and in most cases had low monthly renting costs. Once a retailer reached the end of their working life he/she could sell their business to another entrepreneur and the latter could still maintain the low monthly rent. Thus, older retailers did not see any advantages in modernising their outlets, preferring to wait for the sale of their business, which was then seen as a source of 'retirement fund'. Nevertheless, in the in-depth interviews conducted by the author to 21 business owners (corresponding to 23 establishments because two entrepreneurs had two outlets), it was possible to conclude that some difficulties in relation to conforming to administrative procedures may have diminished the number of outlets that may have adhered to the project. Just one of several reasons, a lack of equity to finance their share of the physical modernisation decreased the number of outlets that adhered to the project. In total, more than 5 million euros was invested into outlets, of which $44 \%$ was through public non-refundable funding. This project also financed an urbanistic intervention in Rossio, as well as diverse small-scale promotional activities (Table 4).

Due to the historical nature of this area, a protocol was established with the Portuguese Institute of Architectural Heritage to ensure that the physical rehabilitation of buildings preserved their historical architectural features. Physical rehabilitation of almost all of the outlets that adhered to Procom were performed. Because retail modernisation happened in Portugal following a significant delay, this project was implemented during a period in which some outlets were still operating with out-dated sales techniques and equipment. This is the reason why in eight establishments, the acquisition of IT equipment and software was financed. Nevertheless, we can see that interventions that were considered as crucial in the global study - such as the professional training of retail employees and managers or the adjustment of the opening hours - were not performed in any establishment (Table 5). 
Table 4. Main characteristics of the Baixa Pombalina PROCOM project.

\begin{tabular}{llr}
\hline Number of supported outlets & 73 \\
Outlets modernisation & Investment $(€)$ & $5,057,859$ \\
& Incentive $(€)$ & $2,249,943$ \\
Urbanistic interventions & Investment $(€)$ & 993,202 \\
& Incentive $(€)$ & 496,601 \\
Promotional activities & Investment $(€)$ & 132,179 \\
& Incentive $(€)$ & 99,135 \\
Total & Investment $(€)$ & $6,183,240$ \\
& Incentive $(€)$ & $2,845,679$ \\
\hline
\end{tabular}

Source: DGAE (2010).

Table 5. Form of intervention performed by outlets.

\begin{tabular}{lc}
\hline Form of intervention & Number of outlets \\
\hline Physical rehabilitation of the outlet & 22 \\
IT equipment & 8 \\
Marketing improvements & 5 \\
Product diversification & 2 \\
Sales techniques improvement & 2 \\
Professional training & 0 \\
Job creation & 0 \\
Opening hours & 0 \\
\hline
\end{tabular}

Source: Interviews performed by the author in November, 2013.

In 14 surveys, the business owners admitted that the modernisation of the establishments was already in place. Because it temporally coincided with the implementation of the Procom project they took advantage of this and minimised the associated modernisation costs they were already facing by adhering to this project. Only in seven cases was the modernisation of the establishment not possible without the financial support from this project.

Even though a huge number of interventions in the area were planned to be carried out - such as the improvement of the accessibility network, arrangement of the urban furniture and the placement of urban signage - the most notorious work that took place was the rehabilitation of Rossio Square, in which parking space for vehicles was eliminated and traffic regulated. A centre for customer support was idealised and opened. However, its only function was to support the establishments with the procedures for the Procom project proposal (Table 6).

The role of the chambers of commerce in Procom was to develop and implement a commercial animation plan for the area of intervention. In the Baixa Pombalina project, this was no different. Still, as happened in the majority of the projects implemented across Portugal (Guimarães 2015), there was a focus on activities which could be quickly implemented but which had limited geographical and temporal impacts, similar to the ones characterised by Stubbs et al. $(2002,322)$ as Footfall builders, which consisted on activities developed on a short period of time, as well as their impacts. 
Table 6. Planned interventions in the intervened area.

\begin{tabular}{ll}
\hline Planned interventions & Achievement \\
\hline Centre for customer support & Yes \\
Rossio street pavement & Yes \\
Pedestrianisation and public space & Partially \\
improvements & \\
Street lighting & Partially \\
Urban furniture & No \\
Urban signage & No \\
Accessibility network & No \\
\hline
\end{tabular}

Source: Interviewee 1 (on January 2014).

Regarding the impacts that arose from the physical modernisation of outlets, from the intervention in Rossio square and from the animation actions developed by the Lisbon chamber of commerce, the majority of respondents felt that the area became more attractive and the retail structure more modern. However, when it came to the impacts on business the answers were not so clear. In fact, the increase in the number of costumers, sales and turnover did not occur as was predicted (Table 7).

Of the 73 establishments that were supported by the project, only 37 remained in the end of 2013 (Table 8). Eleven are still operating but now have a new owner. Twenty-two establishments ceased to exist in the original location and a Google search found no evidence of their existence. This led us to conclude that they lost their viability and ceased their operations. In three cases we could not find their original location and, therefore, it was not possible to discover if they were still operating.

Table 7. Effects of the integrated intervention by the number the respondents.

\begin{tabular}{|c|c|c|c|c|c|c|c|}
\hline \multirow[b]{2}{*}{ Effects } & \multicolumn{7}{|c|}{ Classification } \\
\hline & $\begin{array}{l}1 \text { (Totally } \\
\text { disagree) }\end{array}$ & 234 & 456 & 678 & 89 & $\begin{array}{c}10 \text { (Totally } \\
\text { agree) }\end{array}$ & N/A \\
\hline The area became more attractive & - & $1-3$ & $\begin{array}{lll}3 & 4 & 4\end{array}$ & $\begin{array}{lll}4 & 1 & 5\end{array}$ & $5-$ & 2 & 1 \\
\hline Modernised the retail structure & 1 & -21 & 133 & $3-8$ & $8-$ & - & 3 \\
\hline $\begin{array}{l}\text { Increased the number of } \\
\text { costumers }\end{array}$ & 1 & $\begin{array}{lll}1 & 2 & 1\end{array}$ & 125 & $\begin{array}{lll}5 & 1 & 3\end{array}$ & $3-$ & - & 5 \\
\hline Increased the sales and turnover & 1 & -22 & 236 & $\begin{array}{lll}6 & 1 & 2\end{array}$ & $2-$ & - & 4 \\
\hline
\end{tabular}

Source: Interviews performed by the author in November 2013.

Table 8. Current status of the supported establishments.

\begin{tabular}{lrrr}
\hline \multicolumn{2}{c}{ Status } & No. & (\%) \\
\hline Still & Same owner & 37 & 51 \\
$\quad$ existent & Different owner & 11 & 15 \\
No longer exist & & 22 & 30 \\
Not found & & 3 & 4 \\
Total & & 73 & 100 \\
\hline
\end{tabular}

Source: Pereira (1998); functional survey performed by the author in 2013. 
Table 9. Information about retail evolution in the intervened area.

\begin{tabular}{lc}
\hline Total of units in $1995 / 98$ & 251 \\
Total of units in 2013 & 230 \\
Disappeared since $1995 / 98$ & $128(50.1 \%)$ \\
New in 2013 , compared to $1995 / 98$ & 107 \\
Vacant stores in $1995 / 98$ (without Rossio square) & 10 \\
Vacant stores in 2013 (without Rossio square) & 28 \\
\hline
\end{tabular}

Source: Pereira (1998); functional survey performed by the author (2013).

In general, after comparing the concerned area before and after the intervention we could not find any evidence of the area experiencing a positive evolution. In terms of inhabitants the parish of São Nicolau in which the project was developed lost population, going from 1448 in 1991 to 1175 in 2001. In 2011, this number stabilised and even suffered a small increase. Nevertheless this recent trend is due to a process of return to the centre that has been seen in Lisbon, in close connection with gentrification processes due to the increase of tourists to the city.

Regarding the retail structure, while 251 establishments existed at the end of the 1990 s, in 2013 this number had dropped to 230. Despite the fact that retail is a private sector and has a significant variation rate, what we found is that the number of establishments that closed their activities in this area (128) was higher than the number of establishments that started their activity in that period (107). This demonstrates a lack of viability in the area. This trend correlates with the number of vacant stores, which has increased from 10 to 28 , highlighting the decrease of the viability of the area (Table 9).

The increasing importance of tourism has been important to minimise this negative evolution of the area. Being one of the main tourist sites in Lisbon is appointed by the owners of new establishments as the main reason why they settled in Baixa Pombalina (Guimarães 2015). Consequently, in the present decade, this area has been gaining some relevance and international chain stores have been opening. This has provoked a change in the characteristics of the retail structure, nowadays with less local stores and with more medium-class oriented international outlets, making this area less distinctive and more similar to others, in a process analogous to other national countries, as exemplified by the report 'clone town Britain' (New Economics Foundation 2005).

\section{Concluding remarks and lessons learned}

The Baixa Pombalina Procom project was framed as a municipal policy developed to recentralise that area as the main retail destination, i.e., to reposition this area to the top of the hierarchy of the city retail structure. The evolution of Lisbon retail structure during the period of execution of Procom had as significant exponents the development of two large shopping centres - Colombo and Vasco da Gama - which added two new commercial centralities to the city. Although Vasco da Gama shopping centre is significantly smaller in size, it is located in the area where the 1998 Lisbon World Expo took place. Therefore, the negative impacts arose not only from the shopping centre but also from other small and medium-sized retailers and services that appeared in a new urbanised area of the city.

Returning to the conceptual frameworks presented in Figures 1 and 2, the functional survey and surveys of business owners gave us important insights into the effectiveness of the project and the evolution of the area. This retail regeneration project provided 
significant outputs. The gross impacts were also substantial, mainly because more than 6 million euros were invested into retail modernisation (of which $46 \%$ was with public nonrefundable incentives), public space rehabilitation and commercial animation. However, considering the counterfactual, the surveys allowed us to see that the majority of interventions were already in place. Therefore, there was a substitution of private investment for a public one without any visible advantage.

Overall, what we can conclude from the Baixa Pombalina project in regards to what is useful to similar interventions is that one should not consider interventions in a certain area as if it were a closed system. This project proved that cities are dynamic and are constantly changing, thus, an intervention is likely to be outdated by the time it is completed. This conclusion is in-line with Hall's $(2006,73)$ statement that 'once a regeneration programme or policy has run its course it is likely that cities will be facing new sets of local and global challenges'. Thus, as a final recommendation, more dynamic processes of urban regeneration - such as town centre management, business improvement districts or similar interventions - should be prioritised and be put into practice because they are more dynamic and more adjustable to the constant dynamic of change associated with cities.

In regards to the evaluation, we have concluded that there is a necessity to extend the research to the local level and not give in to the temptation to analyse the general data of projects or ignore the various stakeholders involved. Since it was implemented, the Baixa Pombalina project was considered relevant because of the outputs involved, i.e., a significant amount of funding was distributed to numerous outlets and this allowed for an urbanistic intervention in one major square. Nevertheless, by conducting the interviews we realised that these outputs did not produce significant impacts because the project failed to achieve its main goal of repositioning Baixa Pombalina as the city's main commercial destination. Furthermore, it did not manage to increase the vitality and viability of the area. Regarding other subjects described in Table 3 as the main reasons that led to the need for intervention, the project did not manage to intervene on the rental market. Because it has several urbanistic constraints that do not allow new roads or the enlargement of new ones, nowadays, the area still has inadequacy in face of the dependence of the mobility made by own car. As described between 1991 and 2001, the number of inhabitants decreased and the recent change in this trend is mostly due to gentrification and touristification processes rather than any kind of impact that still arises from Procom. These processes also help explain the opening of new establishments in the area. Therefore, the problem of outdated business practices described at the start of the project was partially solved because several of those establishments went out of business and new ones opened in their place.

With this study, we aim to contribute to the current discussion about urban regeneration, specifically by adding new information about retail-led urban regeneration and for the evaluation of their impacts - aspects that have been neglected in the literature. Because it was not the aim of the paper it was not deepened the subject of retail gentrification. Nevertheless, in this research it became clear its relevance and the necessity of future research on the subject of retail gentrification and its impacts on the traditional retail structures.

\section{Acknowledgements}

We thank the FCT - Portuguese national funding agency for science, research and technology and the Center for Geographical Studies for funding the research on which this paper is based. We are grateful to the editor, Professor Rob Atkinson and the two anonymous reviewers for insightful comments made on a previous version of the paper. We wish to thank Professor Teresa BarataSalgueiro for her support in the research that formed the basis of this paper. 


\section{Disclosure statement}

No potential conflict of interest was reported by the author.

\section{Funding}

This work was supported by FCT - Portuguese national funding agency for science, research and technology [SFRH/BD/69355/2010] and the Center for Geographical Studies from Lisbon University.

\section{ORCID}

Pedro Porfirio Coutinho Guimarães (D) http://orcid.org/0000-0001-9011-8894

\section{References}

Alexander, E. 2006. "Evolution and Status: Where is Planning-Evaluation Today and How Did It Get Here?." In Evaluation in Planning - Evolution and Prospects, edited by E. Alexander, 316. England: Ashgate.

Alpopi, C., and C. Manole. 2013. "Integrated Urban Regeneration - Solution for Cities Revitalize." Procedia Economics and Finance 6: 178-185. doi:10.1016/S2212-5671(13)00130-5.

Balsas, C. 2007. "City Centre Revitalization in Portugal: A Study of Lisbon and Porto." Journal of Urban Design 12 (2): 231-259. doi:10.1080/13574800701306328.

Barata-Salgueiro, T. 1996. Do Comércio à Distribuição - roteiro de uma mudança. Oeiras: Celta Editora.

Barata-Salgueiro, T. 2006. “Oportunidades e transformação na cidade centro.” Finisterra XLI (81): 9-32.

Bell, R., and R. Cuthbertson. 2004. "Collaboration in the Retail Supply Chain." In Retail Strategy, the View from the Bridge, edited by J. Reynolds and C. Cuthbertson, 52-77. Oxford: Elsevier.

Cachinho, H. 2002. O Comércio Retalhista Português. Lisboa: Gabinete de Estudos e Prospectiva Económica.

Castillo-Manzano, J., L. Lopez-Valpuesta, and J. Asencio-Flores. 2014. "Extending Pedestrianization Processes Outside the Old City Center; Conflict and Benefits in the Case of the City of Seville." Habitat International 44: 194-201. doi:10.1016/j. habitatint.2014.06.005.

Claxton, R., and G. Siora. 2008. Retail-Led Regeneration - Why it Matters to Our Communities. Londres: DTZ Consulting. Accessed November 29 2011. http://www.bcsc.org.uk/publication. asp?pub_id=282.

Coca-Stefaniak, J., C. Parker, S. Quin, R. Rinaldi, and J. Byrom. 2009. "Town Centre Management Models: A European perspective." Cities 26 (2): 74-80.

Davis, J., and A. Thornley. 2010. "Urban Regeneration for the London 2012 Olympics: Issues of Land Acquisition and Legacy." City, Culture and Society 1: 89-98. doi:10.1016/j. ccs.2010.08.002.

DGAE.2010. Dinamização económica dos centros históricos. Lisbon: Direcção-Geral das Actividades Económicas.

Dinardi, C. 2015. "Unsettling the Role of Culture as Panacea: The Politics of Culture-Led Urban Regeneration in Buenos Aires." City, Culture and Society 6: 9-18. doi:10.1016/j. ccs.2015.03.003.

Dixton, T., and A. Marston. 2003. The Role of UK Retailing in Urban Regeneration. Reading: College of Estate Management.

Egan, M., L. Lawson, A. Kearns, E. Conway, and J. Neary. 2015. "Neighbourhood Demolition, Relocation and Health. A Qualitative Longitudinal Study of Housing-Led Urban Regeneration in Glasgow, UK." Health \& Place 33: 101-108. doi:10.1016/j.healthplace.2015.02.006.

Emery, J. 2006. "Bullring: A Case Study of Retail-Led Urban Renewal and Its Contribution to City Centre Regeneration." Journal of Retail \& Leisure Property 5 (2): 121-133. doi:10.1057/ palgrave.rlp.5100020. 
European Commission. 2008. EVALSED: The Resource for the Evaluation of Socio-Economic Development. Luxembourg: European Commission.

Fernandes, J. A. 2012. "Os projectos de urbanismo comercial e a revitalização do centro da cidade." Revista Memória em Rede 2 (6): 76-89.

Findlay, A., and L. Sparks. 2009. Literature Review: Policies Adopted to Support a Healthy Retail Sector and Retail Led Regeneration and the Impact of Retail on the Regeneration of Town Centres and Local High Streets. Edimburgo: Scottish Government. Accessed August 32012. http://www.scotland.gov.uk/Publications/2009/01/12112520/0.

Guimarães, P. P. 2013. "The Tools for City Centre Revitalization in Portugal." Journal of Place Management and Development 6 (1): 52-66. doi:10.1108/17538331311306131.

Guimarães, P. P. 2015. "O planeamento comercial em Portugal, os projectos especiais de urbanismo comercial." PhD Dissertation, Universidade de Lisboa.

Guimarães, P. P. forthcoming. "Revisiting Retail Planning Policies in Countries of Restraint of Western Europe." International Journal of Urban Sciences. doi:10.1080/ 12265934.2016.1194225.

Gunay, Z., and V. Dokmeci. 2012. "Culture-Led Regeneration of Istanbul Waterfront: Golden Horn Cultural Valley Project." Cities 29: 213-222.

Guy, C. 2007. Planning for Retail Development, a Critical View of the British Experience. Oxon: Routledge.

Hall, P. 2002. Urban and Regional Planning, 237. 4th ed. London: Routledge.

Hall, T. 2006. Urban Geography. 3rd ed. Oxon: Routledge.

Hoyt, L. 2006. "Importing ideas: The Transnational Transfer of Urban Revitalization Policy." International Journal of Public Administration 29 (1-3): 221-243. doi:10.1080/ 01900690500409096.

Jayne, M. 2006. Cities and Consumption. Nova Iorque: Routledge.

Jones, P., D. Hillier, and D. Comfort. 2003. "Business Improvement Districts in Town and City Centres in the UK." Management Research News 26 (8): 50-59. doi:10.1108/ 01409170310783655.

Jung, T., J. Lee, M. Yap, and E. Ineson. 2015. "The Role of Stakeholder Collaboration in CultureLed Urban Regeneration: A Case Study of the Gwangju Project, Korea." Cities 44: 29-39. doi:10.1016/j.cities.2014.12.003.

Lazarevic, E., A. Koruznjak, and M. Devetakovic. 2015. "Culture Design-Led Regeneration as a Tool Used to Regenerate Deprived Areas. Belgrade - The Savamala Quarter; Reflections on an Unplanned Cultural Zone.” Energy and Buildings 115 (1): 3-10. doi:10.1016/j. enbuild.2015.03.015.

Lee, J. 2013. "Mega-Retail-Led Regeneration and Housing Price." disP - The Planning Review 49 (2): 75-85. doi:10.1080/02513625.2013.827510.

Lowe, M. 2005. "Revitalizing Inner City Retail?: The Impact of the West Quay Development on Southampton." International Journal of Retail \& Distribution Management 33 (9): 658-668. doi:10.1108/09590550510611850.

Lowe, M. 2007. "Rethinking Southampton and Town Centre Futures." International journal of retail \& distribution management 35 (8): 639-464. doi:10.1108/09590550710758621.

Mérenne-Schoumaker, B., and A. Browet. 1988. Localisation du magasin, Guide pratique. Brussels: Comite Belge de la distribution.

New Economics Foundation. 2005. Clone Town Britain. London: New Economics Foundation.

Moore, B., and R. Spires. 2000. "Monitoring and Evaluation." In Urban Regeneration - A Handbook, edited by P. Roberts and H. Sykes, 203-227. London: Sage Publications.

Peel, D., G. Lloyd, and A. Lord. 2009. "Business Improvement Districts and the Discourse of Contractualism." European Planning Studies 17 (3): 401-422. doi:10.1080/ 09654310802618044.

Peel, D., and M. Lloyd. 2005. "A Case for Business Improvement Districts in Scotland: Policy Transfer in Practice?." Planning Practice and Research 20 (1): 89-95. doi:10.1080/ 02697450500261780 .

Pereira, M. (Coord.). 1998. Baixa Pombalina de Lisboa, Estudo Global. Lisbon: Câmara Municipal de Lisboa.

Pereira, M., J. A. Teixeira, and S. Biaggio. 2002. Regulação do equipamento comercial nos países da União Europeia. Lisboa: Gabinete de Estudos e Prospectiva Económica. 
Plaza, B. 2000. "Guggenheim Museum's Effectiveness to Attract Tourism." Annals of Tourism Research 27 (4): 1055-1058. doi:10.1016/S0160-7383(99)00131-0.

Riviezzo, A., A. Nisco, and M. Napolitano. 2009. "Importance-Performance Analysis as a Tool in Evaluating Town Centre Management Effectiveness." International Journal of Retail \& Distribution Management 37 (9): 748-764. doi:10.1108/09590550910975808.

Roberts, P. 2000. "The Evolution, Definition and Purpose of Urban Regeneration." In Urban Regeneration - A Handbook, edited by P. Roberts and H. Sykes, 9-36. London: Sage Publications.

Roberts, P., and H. Sykes. 2000. "Introduction." In Urban Regeneration - A Handbook, edited by P. Roberts and H. Sykes, 3-8. London: Sage Publications.

Robertson, K. 1995. "Downtown Redevelopment Strategies in the United States: An End-of-theCentury Assessment." Journal of the American Planning Association 64 (4): 429-437. doi:10.1080/01944369508975655.

Ruffin, F. 2008. "Professionalizing Business District Management for the Twenty-First Century." Journal of Place Management and Development 1 (1): 29-45. doi:10.1108/ 17538330810865327.

Sasaki, M. 2010. "Urban Regeneration Through Cultural Creativity and Social Inclusion: Rethinking Creative City Theory Through a JAPANESE Case Study.” Cities 27 (1): S3-S9. doi:10.1016/j.cities.2010.03.002.

Stubbs, B., G. Warnaby, and D. Medway. 2002. "Marketing at the Public/Private Sector Interface; Town Centre Management Schemes in the South of England." Cities 19 (5): 317-326. doi:10.1016/S0264-2751(02)00040-9.

Tallon, A. 2008. "Mega-Retail-Led Regeneration." Town and Country Planning 77: 131-137.

Tallon, A. 2010. Urban Regeneration in the UK. London: Routledge.

Tay, P., and A. Coca-Stefaniak. 2010. "Cultural Urban Regeneration - Practice and Policy in the UK and Singapore." Asia Pacific Journal of Arts and Cultural Management 7 (1): 512-527.

Tyler, P., C. Warnock, A. Provins, and B. Lanz. 2013. "Valuing the Benefits of Urban Regeneration." Urban Studies 50 (1): 169-190. doi:10.1177/0042098012452321.

Wang, J. 2009. “'Art in Capital': Shaping Distinctiveness in a Culture-Led Urban Regeneration Project in Red Town, Shanghai.” Cities 26 (6): 318-330. doi:10.1016/j.cities.2009.08.002.

Ward, K. 2007. "Business Improvement Districts: Policy Origins, Mobile Policies and Urban Liveability." Imagining Urban Futures Working Paper 2. Accessed November 30 2011. http:// www.sed.manchester.ac.uk/geography/research/publications/.

Whysall, P. 1995. "Regenerating Innercity Shopping Centres - The British Experience." Journal of Retailing and Consumer Services 2 (1): 3-13. doi:http://dx.doi.org/10.1016/0969-6989(95) 00005-4.

Williams, H. 2014. "Preface." In Evolving High Streets: Resilience \& Reinvention, edited by N. Wrigley and E. Brookes, 2-3. Southampton: ESRC.

Wrigley, N., and E. Brookes. 2014. Evolving High Streets: Resilience \& Reinvention - Perspectives from Social Science. Southampton: ESRC. 